\title{
Data report: reanalysis of interstitial water barium, iron, and sulfur concentrations at Sites U1426 and U1427 ${ }^{1}$
}

\author{
Clint Miller $^{2}$ and Gerald Dickens ${ }^{2}$
}

\section{Chapter contents}

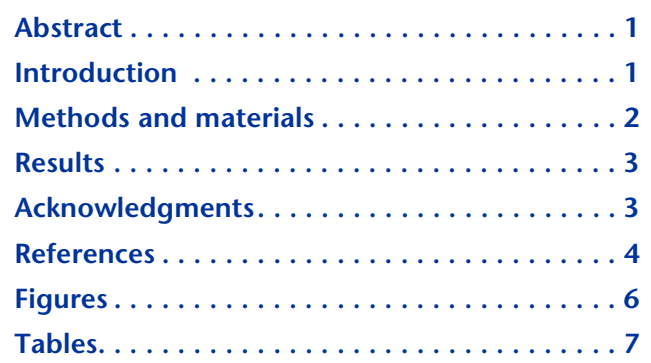

${ }^{1}$ Miller, C., and Dickens, G., 2017. Data report: reanalysis of interstitial water barium, iron, and sulfur concentrations at Sites U1426 and U1427. In Tada, R., Murray, R.W., Alvarez Zarikian, C.A., and the Expedition 346 Scientists, Proceedings of the Integrated Ocean Drilling Program, 346: College Station, TX (Integrated Ocean Drilling Program). doi:10.2204/iodp.proc.346.203.2017

${ }^{2}$ Department of Earth Sciences, Rice University, Houston, TX, 77005, USA. Correspondence author: clint.m.miller@rice.edu

\begin{abstract}
Within the south of the marginal sea between Japan and Korea, interstitial water (IW) profiles exhibit a prominent sulfate-methane transition (SMT) in the upper few meters of sediment. As the SMT has become a focus of attention, IW samples were collected at high spatial resolution within shallow sediment at Sites U1426 and U1427 and examined on board the R/V JOIDES Resolution, under the auspices of the Integrated Ocean Drilling Program, for a wide range of dissolved species. However, irregularities were noted for the sulfate $\left(\mathrm{SO}_{4}{ }^{2-}\right), \mathrm{Ba}$, and $\mathrm{Fe}$ concentration profiles, each of importance to understanding the SMT. Splits of 134 IW samples, prepared with $\mathrm{HNO}_{3}$ during the expedition, were therefore reanalyzed at Rice University for $\mathrm{S}, \mathrm{Ba}$, and $\mathrm{Fe}$, with $\mathrm{S}$ as a proxy for $\mathrm{SO}_{4}{ }^{2-}$. Results of 134 samples included 29 duplicates with low percent difference $(0.01 \%-34.69 \%, 0.01 \%-14.90 \%$, and $0.03 \%-35.19 \%$ ) and 6 spiked blanks with low percent error relative to stock solution concentration $(1.59 \%, 2.41 \%$, and $4.11 \%)$. The shore-based S and Ba profiles have trends similar to those determined on ship but with obvious offsets. The remeasured $\mathrm{Fe}$ profiles are comparable to those measured on ship, albeit with more data points. Although the IW samples were measured between 95 and 113 days after the expedition, the new results have high data reproducibility, render smooth profiles, and give more expected chemistry across the SMTs. For these three elements, we suggest the new results should replace the shipboard data.
\end{abstract}

\section{Introduction}

Anaerobic oxidation of methane (AOM) may be a dominant process in shallow sediment across continental slopes (D'Hondt et al., 2002; Dickens, 2001). During AOM, downward diffusing sulfate reacts with upward migrating methane as follows (Reeburgh, 1976, Barnes and Goldberg, 1976):

$$
\mathrm{CH}_{4}+\mathrm{SO}_{4}{ }^{2-} \rightarrow \mathrm{HCO}_{3}{ }^{-}+\mathrm{HS}^{-}+\mathrm{H}_{2} \mathrm{O} \text {. }
$$

The microbially mediated reaction (Boetius et al., 2000) typically occurs across a relatively thin and conspicuous geochemical horizon (Devol and Ahmed, 1981), generally now referred to as the sulfate-methane transition (SMT). Other than producing bicarbonate and hydrogen sulfide ions, AOM indirectly affects the 
chemistry of other elements, notably $\mathrm{Ba}, \mathrm{Ca}, \mathrm{Fe}, \mathrm{Mg}$, and Sr. This is because of precipitation and dissolution of various minerals (e.g., barite, calcite, greigite) within sediment at or near the SMT (Torres et al., 1996; Dickens, 2001; Luff and Wallmann, 2003; Snyder et al., 2007.

Although both AOM and associated SMTs are now widely discussed in the scientific literature, a full understanding of chemical impacts across the SMT remains uncertain. This is because many sites where $\mathrm{AOM}$ has been suggested lack high-resolution interstitial water (IW) sampling over an extended sedimentary depth, a full suite of pertinent analyses, or both. Previous work in the marginal sea between the Eurasian continent, the Korean Peninsula, and the Japanese Islands (hereafter simply called the "marginal sea"; Fig. F1) highlights this issue. For example, at Ocean Drilling Program (ODP) Site 798, which presumably has a SMT, measurements of dissolved $\mathrm{SO}_{4}{ }^{2-}$ and $\mathrm{Ba}$ were made approximately every $5.5 \mathrm{~m}$ and $20 \mathrm{~m}$, respectively (Shipboard Scientific Party, 1990). Along Umitaka Spur, Snyder et al. (2007) determined alkalinity and dissolved $\mathrm{S}, \mathrm{Ba}, \mathrm{Ca}, \mathrm{Mg}$, and $\mathrm{Sr}$ at high sample resolution, but without measurements of $\mathrm{CH}_{4}$ or dissolved $\mathrm{HS}^{-}$, and the piston cores only penetrated $4 \mathrm{~m}$ of sediment.

A shallow SMT probably occurs in sediment across much of the southern marginal sea (Fig. F1). In 2013, International Ocean Drilling Program (IODP) drilled seven locations in the marginal sea. Site U1426 is located at $37^{\circ} 2.00^{\prime} \mathrm{N}, 134^{\circ} 48.00^{\prime} \mathrm{E}$, and $902 \mathrm{~m}$ water depth at the same location as ODP Site 798. Four holes at Site U1426 penetrated 396, 34, 204, and 99 meters below seafloor (mbsf) with recovery $<100 \%$ (see the "Site U1426" chapter [Tada et al., 2015b]). Site U1427 is located at $35^{\circ} 57.92^{\prime} \mathrm{N}, 134^{\circ} 26.06^{\prime} \mathrm{E}$, and $330 \mathrm{~m}$ water depth. Three holes at Site U1427 cored 548,405 , and 351 mbsf with a recovery $<98.9 \%$ (see the "Site U1427" chapter [Tada et al., 2015c]). While principally drilled for paleoceanographic objectives, an additional focus at these sites in the southern marginal sea was generation of high-resolution IW profiles for a wide array of dissolved species. This mission was accomplished, but as noted in the "Site U1426" and "Site U1427" chapters (Tada et al., 2015 b, 2015c), there were some data irregularities with shipboard $\mathrm{SO}_{4}{ }^{2-}$ and $\mathrm{Ba}$ measurements (Fig. F2). The $\mathrm{SO}_{4}{ }^{2-}$ concentrations did not reach micromolar concentrations below the SMT as expected from abundant work at locations around the world, including piston core KH-77-3-L4 located $54 \mathrm{~km}$ northeast of Site U1426 (Fig. F1; Masuzawa and Kitano, 1983). The dissolved Ba concentrations were approximately one order of magnitude higher than those measured at ODP Site 798. The dissolved Fe concentrations were only measured on a few samples.

Here, we reexamine most of the pore water splits by inductively coupled plasma-atomic emission spectroscopy (ICP-AES) at Rice University approximately 4 months after the expedition (Fig. F3). The analyses include $\mathrm{S}$, which we use a proxy for $\mathrm{SO}_{4}{ }^{2-}, \mathrm{Ba}$, and $\mathrm{Fe}$. Smooth high-resolution and internally consistent concentration profiles were determined for most solutes on board ship, including $\mathrm{Ca}$ and $\mathrm{Mg}$, so we purposely tuned analyses to these three elements and did not measure any other analytes.

\section{Methods and materials}

\section{Interstitial water collection}

Interstitial water samples were extracted from sediment cores using two methods: whole-round squeezing and Rhizon sampling (see the "Methods" chapter [Tada et al., 2015a]). In general, two whole-round samples were taken per core, usually at the base of Sections 1 and 4 . Rhizon samples then were obtained at higher resolution in Holes B and C, especially where Hole A showed major changes in chemical gradients. This combined strategy resulted in an IW sample approximately every $25-50 \mathrm{~cm}$ over the upper $40 \mathrm{~m}$ at Sites U1426 and U1427. Separate aliquots were taken from the IW samples for a range of measurements. On the ship, this included salinity, alkalinity and $\mathrm{pH}$, major anions $\left(\mathrm{Cl}^{-}, \mathrm{SO}_{4}{ }^{2-}, \mathrm{Br}^{-}\right)$and cations $(\mathrm{Ca}, \mathrm{Mg}, \mathrm{K}, \mathrm{Na})$, minor elements $(\mathrm{B}, \mathrm{Ba}, \mathrm{Fe}$, $\mathrm{Li}, \mathrm{Mn}, \mathrm{Sr})$, ammonium $\left(\mathrm{NH}_{4}{ }^{+}\right)$, phosphate $\left(\mathrm{PO}_{4}{ }^{3-}\right)$, silica $\left(\mathrm{H}_{4} \mathrm{SiO}_{4}\right)$, hydrogen sulfide (HS'), and "yellowness." The results of these analyses were presented in the "Site U1426" and "Site U1427" chapters (Tada et al., 2015b, 2015c).

A separate set of IW aliquots, each between 0.5 and 5 $\mathrm{mL}$ in volume, were placed in $3 \mathrm{~mL}$ plastic vials, "preserved" by adding $10 \mu \mathrm{L}$ of ultrapure $\mathrm{HNO}_{3}$, and stored in a shipboard refrigerator. Following the expedition, these aliquots were shipped to Houston, Texas, but stayed in customs for several weeks. When the samples arrived at Rice University, they were immediately placed in refrigerators; however, they likely reached ambient temperatures while in customs.

\section{Interstitial water analyses}

A total of 134 IW samples from Site U1426 (105) and U1427 (29) were reanalyzed (Table T1). For 29 of these samples, replicate analyses were made to assess analytical precision. Shore-based analyses occurred 
on 31 December 2013 (52), 13 January 2014 (83), and 18 January 2014 (28), 95-113 days after the expedition (Table T2). However, no damaged or otherwise compromised vials were observed.

Concentrations of $\mathrm{S}, \mathrm{Ba}$, and Fe were measured with an Agilent Vista Pro ICP-AES housed in the geochemistry facilities at Rice University. Standards were prepared by diluting International Association for the Physical Sciences of the Ocean (IAPSO) P-series seawater and Fisher Scientific reference standard certified solutions of known concentrations (Gieskes et al., 1991). IW samples were diluted 1:20 with deionized water ( $>18 \mathrm{M} \Omega$ resistivity). Scandium $(10 \mu \mathrm{L}$; NIST-traceable certified reference material) was added to standards and samples to correct for instrumental drift $(\mathrm{Sc}$ emission line $=361.383 \mathrm{~nm}$ ). Wavelengths used for elemental analysis were 181.972, 493.403, and $238.204 \mathrm{~nm}$ for $\mathrm{S}, \mathrm{Ba}$, and $\mathrm{Fe}$, respectively.

Two blanks and one $\mathrm{S}$ and $\mathrm{Ba}$ standard solution spiked control sample were placed every 20 samples. Of the duplicate samples, 21 of the 29 were analyzed on a different day than the original. The method detection limit (MDL) for each species is determined by the following equation (Skoog et al., 2007):

$$
\mathrm{MDL}=\left(\frac{\mathrm{C}_{\mathrm{High}}-\mathrm{C}_{\text {Low }}}{\mathrm{I}_{\mathrm{High}}-\mathrm{I}_{\text {Low }}}\right) 3 \sigma,
$$

where $\mathrm{C}=$ concentration and $\mathrm{I}=$ intensity (counts per second on the ICP-AES).

\section{Results}

Measured concentrations at Site U1426 ranged 0.09$28.57 \mathrm{mM}(\mathrm{S}), 0.11-110.9 \mu \mathrm{M}(\mathrm{Ba})$, and $0.14-32.3$ $\mu \mathrm{M}(\mathrm{Fe})$. At Site U1427, these concentrations ranged 0.12-28.53 mM, 0.06-9.24 $\mu \mathrm{M}$, and 0.15-25.7 $\mu \mathrm{M}$. The MDLs were $1.2 \mu \mathrm{M}$ for $\mathrm{S}, 0.01 \mu \mathrm{M}$ for $\mathrm{Ba}$, and $0.09 \mu \mathrm{M}$ for Fe. Blank concentrations were below MDLs for all analytes in every sample. Spiked sample percent error was $1.59 \%, 2.41 \%$, and $4.11 \%$. Duplicate percent difference ranged $0.01 \%-34.69 \%$, $0.01 \%-14.90 \%$, and $0.03-5.19 \%$ for $\mathrm{S}, \mathrm{Ba}$, and $\mathrm{Fe}$ with average percent difference for all duplicates of $5.22 \%, 5.69 \%$, and $12.55 \%$. Strictly speaking, Fe concentrations should be reported with two significant figures; however, they are listed with three in Table T1 for comparison with shipboard data.

Smooth concentration profiles occur for all three elements at both sites. The maximum percent difference of "depth adjacent" samples, defined as the nearest sample in depth, is $<98.18 \%, 79.17 \%$, and
$146.15 \%$ for $\mathrm{S}, \mathrm{Ba}$, and $\mathrm{Fe}$ (averages $=20.84 \%$, $12.56 \%$, and $28.69 \%$ ). Although this calculation has little quantitative significance, it indicates a high degree of depth continuity, as expected for "diffusion dominated" systems. In short, the concentration profiles exhibit little scatter.

At Site U1426, S concentrations from the mudline to 7 mbsf are similar to $\mathrm{SO}_{4}{ }^{2-}$ concentrations measured on board the ship as well at Site 798 and piston core KH-77-3-L4; decreasing from $\sim 28$ to $\sim 5 \mathrm{mM}$. Below 7 mbsf, however, $\mathrm{S}$ concentrations diverge from those determined on ship but follow the limited values determined at Site 798. Shipboard concentrations approach $\sim 2 \mathrm{mM}$ and roughly stay at this concentration. By contrast, the shore-based concentrations reach submillimolar levels at $9.56 \mathrm{mbsf}$ and decrease to $0.14 \mathrm{mM}$ at 37.39 mbsf. Likewise, Ba concentrations are similar to Site 798; however, shipboard results are 10 times higher.

Site U1427 S concentrations from the mudline to 5 mbsf are similar to $\mathrm{SO}_{4}{ }^{2-}$ concentrations examined on board the R/V JOIDES Resolution ( 28-2.09 mM). Below $5 \mathrm{mbsf}$, $\mathrm{S}$ concentrations decrease to submillimolar concentrations at $6.95 \mathrm{mbsf}$, but shipboard $\mathrm{SO}_{4}{ }^{2-}$ results do not decrease to less than $1.83 \mathrm{mM}$. Site U1427 Ba concentrations are consistently at $1 / 10$ shipboard concentrations. Fe concentrations at Sites U1426 and U1427 follow shipboard profiles but have higher depth resolution.

Expedition 346 had one of the fastest core flow rates in the history of scientific drilling $(\sim 6.3 \mathrm{~km}$ of sediment recovered over $\sim 6$ weeks; see the "Methods" chapter [Tada et al., 2015a]). Inserting a high-resolution IW sampling program into such a cruise almost predictably led to issues: some IW samples could not be analyzed, and some analyses (although wrong) could not be correct in real time. The shipboard $\mathrm{SO}_{4}{ }^{2-}$ and $\mathrm{Ba}$ data determined for pore water at Sites $\mathrm{U} 1426$ and $\mathrm{U} 1427$ did not make sense. The $\mathrm{SO}_{4}{ }^{2-}$ concentrations did not approach zero below the SMT, and the Ba concentrations were astonishingly high. Since the shipboard analyses gave "smooth" profiles, we assume the errors lie with calibration and the accuracy of measurements. We suggest that for $\mathrm{S}, \mathrm{Ba}$, and Fe the shipboard data should be replaced with this new data set.

\section{Acknowledgments}

We thank the captain and crew of the JOIDES Resolution for a successful expedition. This research used 
samples and/or data provided by the Integrated Ocean Drilling Program (IODP). The U.S. National Science Foundation (NSF) sponsored IODP.

\section{References}

Barnes, R.O., and Goldberg, E.D., 1976. Methane production and consumption in anoxic marine sediments. Geology, 4(5):297-300. https://doi.org/10.1130/00917613(1976)4<297:MPACIA>2.0.CO;2

Boetius, A., Ravenschlag, K., Schubert, C.J., Rickert, D., Widdel, F., Gieseke, A., Amann, R., Jørgensen, B.B., Witte, U., and Pfannkuche, O., 2000. A marine microbial consortium apparently mediating anaerobic oxidation of methane. Nature, 407(6804):623-626. https://doi.org/10.1038/35036572

D'Hondt, S., Rutherford, S., and Spivack., A.J., 2002. Metabolic activity of subsurface life in deep-sea sediments. Science, 295(5562):2067-2070. http://dx.doi.org/ 10.1126/science. 1064878

Devol, A.H., and Ahmed, S.I., 1981. Are high rates of sulphate reduction associated with anaerobic oxidation of methane? Nature, 291(5814):407-408. https://doi.org/ $10.1038 / 291407 \mathrm{a} 0$

Dickens, G.R., 2001. Sulfate profiles and barium fronts in sediment on the Blake Ridge: present and past methane fluxes through a large gas hydrate reservoir. Geochimica et Cosmochimica Acta, 65(4):529-543. https://doi.org/10.1016/S0016-7037(00)00556-1

Gieskes, J.M., Gamo, T., and Brumsack, H., 1991. Technical Note 15: Chemical Methods for Interstitial Water Analysis Aboard JOIDES Resolution. Ocean Drilling Program. http://dx.doi.org/10.2973/odp.tn.15.1991

Luff, R., and Wallmann, K., 2003. Fluid flow, methane fluxes, carbonate precipitation and biogeochemical turnover in gas hydrate-bearing sediments at Hydrate Ridge, Cascadia margin: numerical modeling and mass balances. Geochimica et Cosmochimica Acta, 67(18):3403-3421. https://doi.org/10.1016/S00167037(03)00127-3

Masuzawa, T., and Kitano, Y., 1983. Sulfate reduction and sulfide deposition in deep-sea sediments from the southwestern Japan Sea. Journal of Oceanography Society of Japan, 39(5):251-258. https://doi.org/10.1007/BF02070395

Miller, C.M., Dickens, G.R., Jakobsson, M., Johansson, C., Koshurnikov, A., O'Regan, M., Muschitiello, F., Stranne, C., and Mörth, C.-M., 2017. Pore water geochemistry along continental slopes north of the East Siberian Sea: inference of low methane concentrations. Biogeosciences, 14(12):2929-2953. https://doi.org/10.5194/bg-14-2929-2017

Reeburgh, W.S., 1976. Methane consumption in Cariaco Trench waters and sediments. Earth and Planetary Science Letters, 28(3):337-344. https://doi.org/10.1016/0012-821X(76)90195-3
Shipboard Scientific Party, 1990. Site 798. In Ingle, J.C., Jr., Suyehiro, K., von Breymann, M.T., et al., Proceedings of the Ocean Drilling Program, Initial Reports, 128: College Station, TX (Ocean Drilling Program). https://doi.org/10.2973/odp.proc.ir.128.105.1990

Skoog, D.A., Holler, F.J., and Crouch, S.R., 2007. Principles of Instrumental Analysis (6th edition): Salt Lake City, Utah (Brooks Cole Publishing Co).

Snyder, G.T, Hiruta, A., Matsumoto, R., Dickens, G.R., Tomaru, H., Takeuchi, R., Komatsubara, J., Ishida, Y., and $\mathrm{Yu}, \mathrm{H} ., 2007$. Pore water profiles and authigenic mineralization in shallow marine sediments above the methane-charged system on Umitaka Spur, Japan Sea. Deep-Sea Research, Part II, 54(11-13):1216-1239. https://doi.org/10.1016/j.dsr2.2007.04.001

Tada, R., Murray, R.W., Alvarez Zarikian, C.A., Anderson, W.T., Jr., Bassetti, M.-A., Brace, B.J., Clemens, S.C., da Costa Gurgel, M.H., Dickens, G.R., Dunlea, A.G., Gallagher, S.J., Giosan, L., Henderson, A.C.G., Holbourn, A.E., Ikehara, K., Irino, T., Itaki, T., Karasuda, A., Kinsley, C.W., Kubota, Y., Lee, G.S., Lee, K.E., Lofi, J., Lopes, C.I.C.D., Peterson, L.C., Saavedra-Pellitero, M., Sagawa, T., Singh, R.K., Sugisaki, S., Toucanne, S., Wan, S., Xuan, C., Zheng, H., and Ziegler, M., 2015a. Methods. In Tada, R., Murray, R.W., Alvarez Zarikian, C.A., and the Expedition 346 Scientists, Proceedings of the Integrated Ocean Drilling Program, 346: College Station, TX (Integrated Ocean Drilling Program). http://dx.doi.org/10.2204/iodp.proc.346.102.2015

Tada, R., Murray, R.W., Alvarez Zarikian, C.A., Anderson, W.T., Jr., Bassetti, M.-A., Brace, B.J., Clemens, S.C., da Costa Gurgel, M.H., Dickens, G.R., Dunlea, A.G., Gallagher, S.J., Giosan, L., Henderson, A.C.G., Holbourn, A.E., Ikehara, K., Irino, T., Itaki, T., Karasuda, A., Kinsley, C.W., Kubota, Y., Lee, G.S., Lee, K.E., Lofi, J., Lopes, C.I.C.D., Peterson, L.C., Saavedra-Pellitero, M., Sagawa, T., Singh, R.K., Sugisaki, S., Toucanne, S., Wan, S., Xuan, C., Zheng, H., and Ziegler, M., 2015b. Site U1426. In Tada, R., Murray, R.W., Alvarez Zarikian, C.A., and the Expedition 346 Scientists, Proceedings of the Integrated Ocean Drilling Program, 346: College Station, TX (Integrated Ocean Drilling Program). https://doi.org/10.2204/iodp.proc.346.107.2015

Tada, R., Murray, R.W., Alvarez Zarikian, C.A., Anderson, W.T., Jr., Bassetti, M.-A., Brace, B.J., Clemens, S.C., da Costa Gurgel, M.H., Dickens, G.R., Dunlea, A.G., Gallagher, S.J., Giosan, L., Henderson, A.C.G., Holbourn, A.E., Ikehara, K., Irino, T., Itaki, T., Karasuda, A., Kinsley, C.W., Kubota, Y., Lee, G.S., Lee, K.E., Lofi, J., Lopes, C.I.C.D., Peterson, L.C., Saavedra-Pellitero, M., Sagawa, T., Singh, R.K., Sugisaki, S., Toucanne, S., Wan, S., Xuan, C., Zheng, H., and Ziegler, M., 2015c. Site U1427. In Tada, R., Murray, R.W., Alvarez Zarikian, C.A., and the Expedition 346 Scientists, Proceedings of the Integrated Ocean Drilling Program, 346: College Station, TX (Integrated Ocean Drilling Program). http://dx.doi.org/10.2204/iodp.proc.346.108.2015 
Torres, M.E., Brumsack, H.-J., Bohrmann, G., and Emeis, K.C., 1996. Barite fronts in continental margin sediments: a new look at barium remobilization in the zone of sulfate reduction and formation of heavy barites in diagenetic fronts. Chemical Geology, 127(1-3):125-139. https://doi.org/10.1016/0009-2541(95)00090-9
Initial receipt: 21 April 2017

Acceptance: 3 August 2017

Publication: 3 October 2017

MS 346-203 
Figure F1. Map of the "marginal sea" showing drill sites and locations with a shallow SMT.

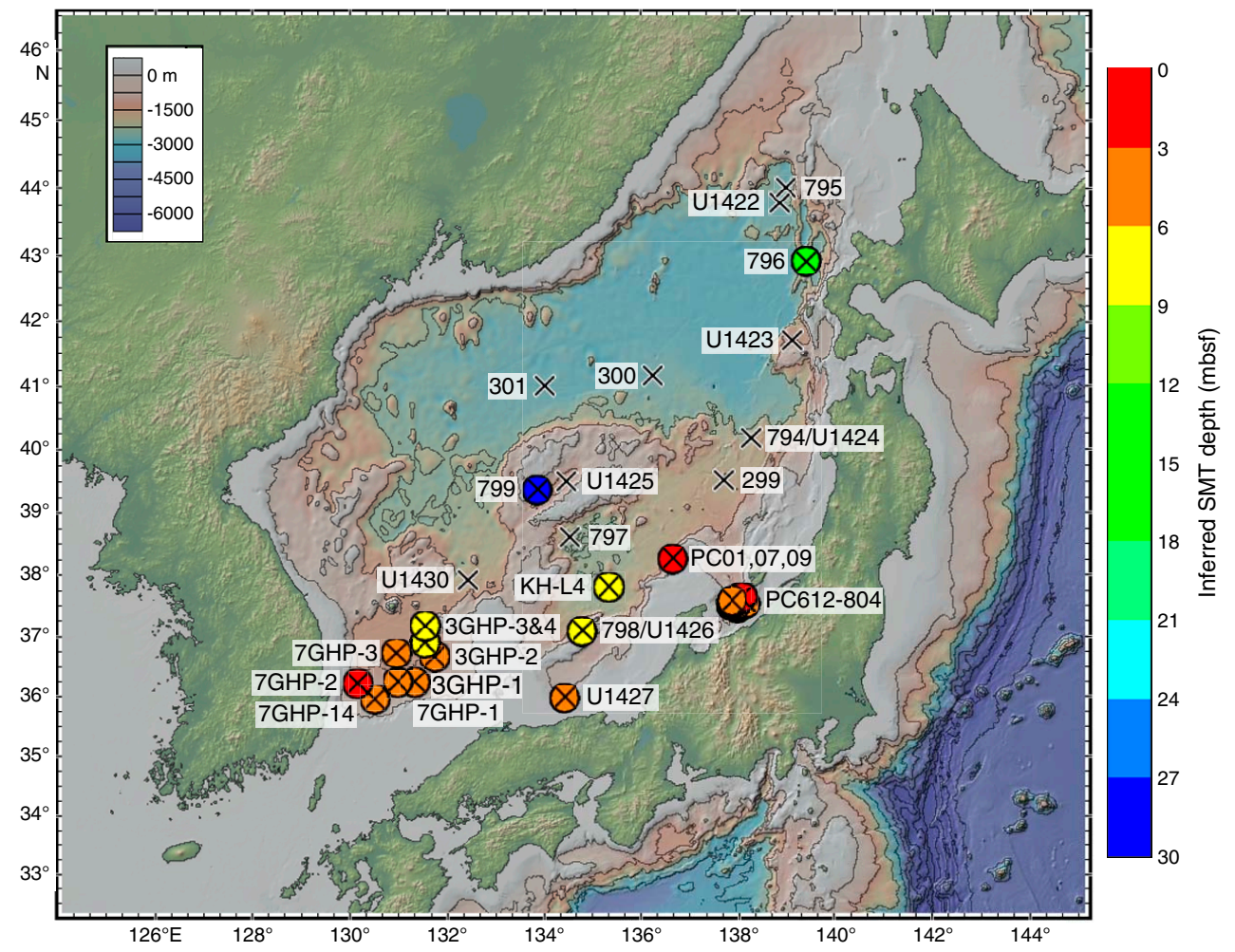

Figure F2. Sulfate data at core KH-77-3-L4, Sites 798, and U1426 (shipboard).

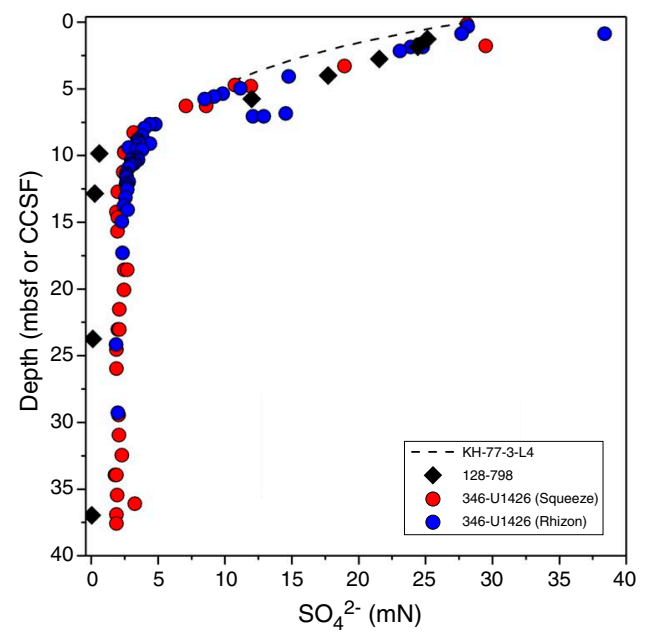


Figure F3. Sulfate/sulfur, barium, and iron data at Sites U1426 and U1427 compared with shore-based results. Rhizon and squeeze collection techniques are differentiated with color.
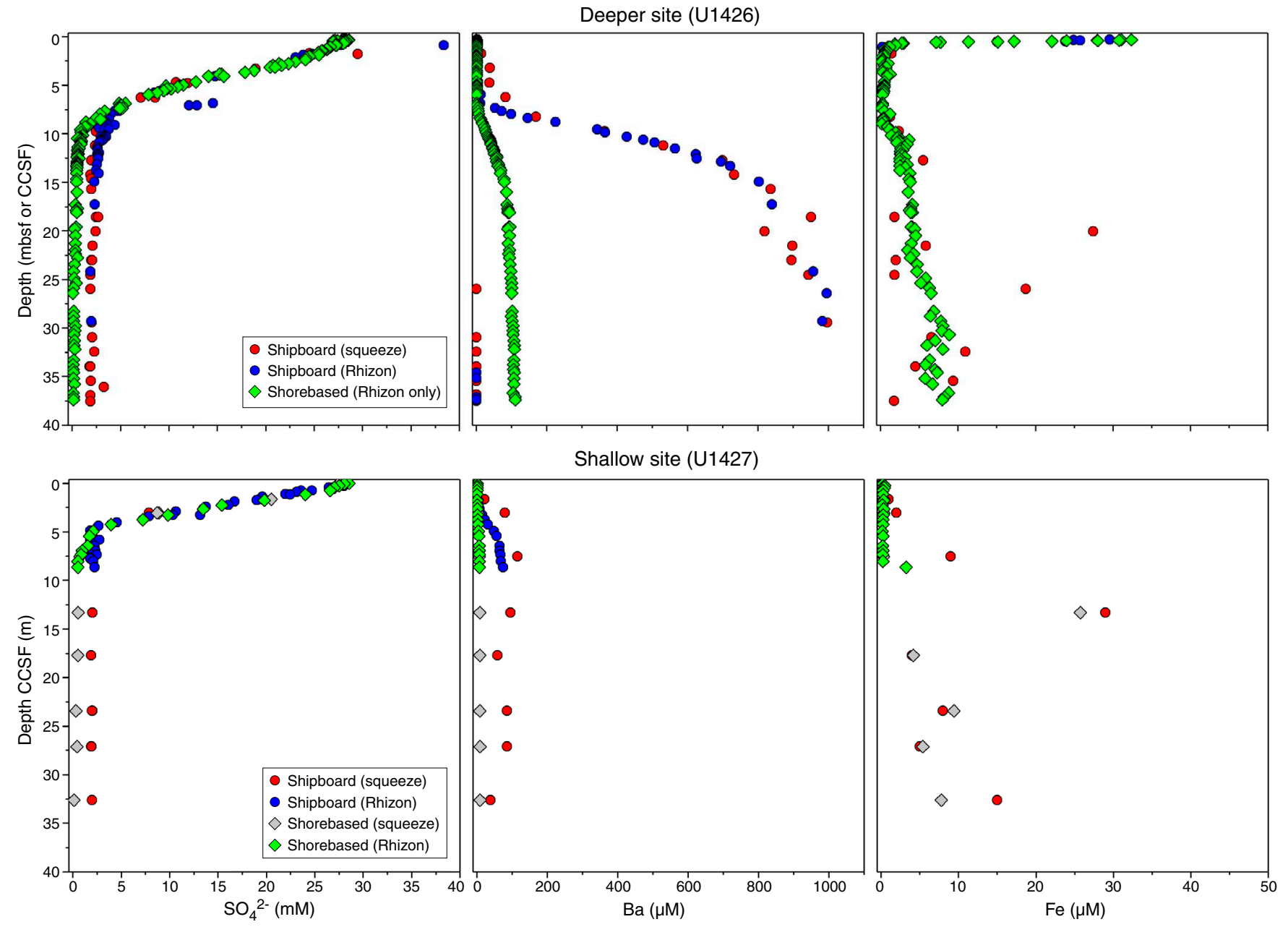

Table T1. Shipboard and shore-based results, Sites U1426 and U1427. This file is available in CSV format.

Table T2. Dates of shore-based analyses. This file is available in CSV format. 